\title{
ОСЛОЖНЕНИЯ И АВАРИИ ПРИ БУРЕНИИ ЭКСПЛУАТАЦИОННЫХ СКВАЖИН И БОКОВЫХ СТВОЛОВ
}

\author{
К. В. Антонов, Д. Д. Жумабаев, А. П. Грабовская, \\ Башкирский государственный университет, г. Уфа, Башкортостан, Россия
}

\section{DOI: https://doi.org/10.31435/rsglobal_conf/30042021/7528}

Abstract. The paper describes the full cycle of drilling a vertical well, where complications occurred from the conductor's shoe to the project face. In the well section, complications in the form of drilling fluid absorption were present almost throughout the entire drilling process and were simultaneously accompanied by several accidents.

When drilling in the wells of side shafts, accidents presented by scrapping and tacking of drilling tools are considered.

Keywords: complication, accident, well, absorption, bit, drilling mud, tack, descent, lifting, tool landing, flushing, working, circulation, core-collecting projectile, cement bridge.

Одним из факторов успешного развития государства и процветания его общества является уровень энергетического потенциала представляемого на данном этапе углеводородным сырьем, включающим нефть, природный газ, газовый конденсат, обеспечивающих работу промышленности, транспорта и быт населения. Углеводородный потенциал оценивается в прогнозных ресурсах, промышленных запасах и непосредственно в количестве добываемых объемов нефти и газа. При этом от прогноза до добычи углеводородного сырья проходит ряд последовательных этапов геологоразведочных работ. На всех этапах геологоразведочных работ используется широкий спектр геологических, геофизических, геохимических, дистанционных методов исследования земных недр. Выполняя свои задачи, эти методы служат в качестве инструмента выявления и подготовки объектов к поисковому бурению или разведке и доразведке участков месторождений. Открыть месторождение и осуществлять добычу нефти и газа можно исключительно посредством бурения скважины. Скважина относится к объектам капитального строительства, а сооружение ее осуществляется с поверхности земли и без доступа в нее человека. Именно это и определяет специфику и особенность строительства скважины.

Успешность строительства скважины во многом предопределяет степень изученности геологического разреза вскрываемого скважиной, техническое и технологическое оснащение, квалификационный уровень профессиональных знаний и умений буровой бригады, уровень профессиональной подготовки инженерно-технических специалистов всех уровней имеющих отношение к сооружению скважины. И не смотря на все допустимые благоприятные условия, осложнения и аварии все же встречаются на разных этапах строительства отдельных скважин.

Осложнение представляет собой нарушение нормального процесса строительства скважины, требующее принятия безотлогательнах и эффективных мер для его устранения и продолжения бурения.

К осложнениям в процессе бурения глубоких скважин относятся: поглощения бурового и тампонажного растворов, газонефтеводопроявления через устье скважины (переливы, выбросы, фонтаны) и за пределами устья (грифоны), обвалообразования, желобообразования, образования уступов и резких искривлений ствола скважины, прихваты и заклинивания бурильной и обсадной колонны, растепление многолетнемерзлых пород.

Аварией считается нарушение непрерывности технологического процесса строительства (бурения и испытания) скважины, требующее для его ликвидации проведения специальных работ, не предусмотренных проектом.

Аварии в процессе бурения скважины бывают связаны с поломкой и оставлением в скважине частей бурильной или обсадной колонн, долот, забойных двигателей, потерей подвижности (прихватом) колонны бурильных и обсадных труб, падением в скважину посторонних предметов. 
Мероприятия по предупреждению аварий являются важным фактором снижения аварийности. Эти мероприятия могут быть самыми разнообразными - организационными, технологическими и техническими.

Авария может быть успешно ликвидирована при правильной оценке причин, состояния и выборе способа ее ликвидации, в частности извлечения аварийного бурильного инструмента из скважины. Все мероприятия по ликвидации аварии (прихвата) необходимо выполнять быстро и организованно; чем дольше находится инструмент в скважине без движения, тем труднее будет его извлечь.

Граница между осложнением и аварией так тонка и прозрачна, что в ряде случаев осложнения переходят в аварии.

Вместе с тем, при бурении скважин встречаются разного рода осложнения, аварии и инциденты, предупредить или в максимально короткие сроки ликвидировать их является одной из важнейших задач обеспечивающих быстрое и качественное сооружение горных выработок представляемых скважинами. Накапливаемым и постоянно пополняемым опытом ликвидации осложнений и аварий в процессе бурения не следует пренебрегать, а анализировать и максимально эффективно использовать его в сходных геолого-технологических условиях. При том очень важно, что каждая скважина индивидуальна и несет ценную технологическую, и геологическую информации о строении недр и его промышленном потенциале [1].

Произошедшие осложнения и аварии рассмотриваются на примерах завершенных строительством скважинах не только как свершившийся факт, но и с позиции обстоятельств, предшествовахших возникновению и последующей ликвидации осложнения и аварии.

Скважина № 1 ЛГВ закладывалась с целью уточнения залежей нефти и газа в каменноугольных и девонских отложениях палеозоя.

Бурение, спуск и цементирование шахтного $(8 \mathrm{M} \times 530$ мм $)$ и удлиненного (133,57 м × 426 мм, диаметр долота 508 мм) направлений выполнены без осложнений. В качестве бурового использовался глинистый раствор с параметрами: плотность 1,07 г/см вязкость 50-60 сек, водоотдача $14 \mathrm{~cm}^{3} / 30$ мин.

Бурение под кондуктор диаметром 324 мм велось долотом диаметром 393,7 мм в интервале 133,57-892 м с промывкой полимерглинистым раствором с параметрами: плотность

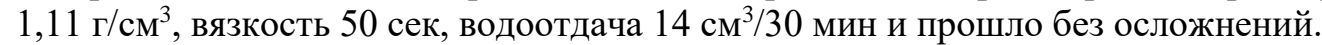

При проведении геофизических исследований (при забое 892 м) под кондуктор приборы вставали на глубине 730 м, произвели проработку и подготовку ствола к спуску кондуктора.

При спуске обсадной колонны диаметром 324 мм на глубине 772 м произошла посадка колонны и прихват. Навернули промывочный переводник, промыли скважину и приступили к расхаживанию колонны: натяжка до 85 тн, разгрузка до 37,6 тн положительных результатов не достигли. Установили нефтяную ванну в объеме $27 \mathrm{~m}^{3}$, после чего колонна была освобождена. Произвели подъем колонны с выбросом труб на мостки. После обработки бурового раствора повторно проработали ствол скважины в интервале 204-892 м и произвели беспрепятственный спуск и цементирование колонны.

Бурение под техническую колонну диаметром 245 мм производилось долотами диаметром 295,3 мм, полимерглинистым буровым раствором с параметрами: плотность

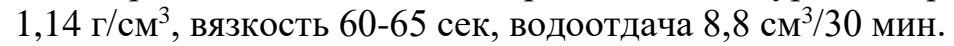

При бурении в интервале 1066-1086 м вскрыли зону поглощения, поглотило $15 \mathrm{~m}^{3}$ бурового раствора. После заготовки раствора бурение продолжили с частичным поглощением. При забое 1131 м произошло полное поглощение бурового раствора. Подняли инструмент на глубину 865 м, заготовили и закачали вязкую пачку в объеме 27 м $^{3}$ - на устье вышло 0,2 м ${ }^{3}$ раствора. Вторично закачали вязкую пачку в объеме $15 \mathrm{~m}^{3}$, буровой раствор вышел на устье через 12 мин. В третий раз закачали вязкую пачку, циркуляция на устье появилась через 3 мин.

Бурение в интервале 1131-1176 м проводилось с частичным поглощением бурового раствора интенсивностью 3,8 м $^{3}$ в час. На глубине 1176 м вскрыта зона поглощения с полной потерей циркуляции. Закачки в скважину вязких пачек результатов не дали.

Произвели проработку скважины и спустили открытый конец СБТ 127. Заготовили и закачали в скважину $128 \mathrm{~m}^{3}$ высоковязкого бурового раствора, циркуляцию восстановить не удалось. 
Произвели заливку зоны поглощения путем закачки $11 \mathrm{~m}^{3}$ цементного раствора плотностью 1,50 г $/ \mathrm{cm}^{3}$. Отрытый конец бурового инструмента при заливке находился на глубине 855 м. После ОЗЦ произвели проработку ствола скважины. На глубине 1175 м произошло полное поглощение бурового раствора. Скважина поглотила $41 \mathrm{~m}^{3}$ бурового раствора. Для ликвидации поглощения заготовили $70 \mathrm{~m}^{3}$ бурового раствора с наполнителем -

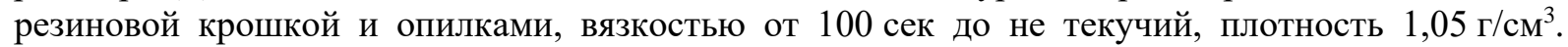
Спустили инструмент с открытым концом СБТ 127 и закачали раствор, циркуляция не восстановилась, поглотив весь раствор.

Произвели повторную заливку зоны поглощения путем закачки $6 \mathrm{~m}^{3}$ цементного

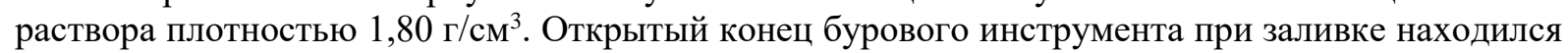
на глубине 1115 м.

По истечению времени ОЗЦ спустили компоновку на глубину 892 м и приступили к восстановлению циркуляции, циркуляция в скважине появилась после прокачки $11 \mathrm{~m}^{3}$ бурового раствора. Продолжили спуск компоновки на бурение. На глубине 1059 м произошла посадка и заклинка бурового инструмента.

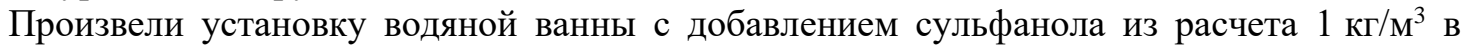
объеме $22 \mathrm{~m}^{3}$ с расхаживанием инструмента и прокачкой через каждый час по $2 \mathrm{~m}^{3}$, что обеспечило освобождение инструмента, но во время отворота трубы инструмент снова прилип. Промывку скважины с расхаживанием продолжили и установили вторую водяную ванну с добавлением сульфанола в объем $18 \mathrm{~m}^{3}$. Расхаживание инструмента под водяной ванной привело к освобождению инструмента. Подъем инструмента в интервале 1050-892 м происходил с затяжками.

Сменили КНБК и приступили к спуску. На глубине 907 м произошла посадка инструмента, дальнейший спуск производился с проработкой в интервале 907-1130 м. Для восстановления циркуляции в скважину закачали $11,5 \mathrm{~m}^{3}$ бурового раствора. За время проработки и промывки произошло поглощение $13 \mathrm{~m}^{3}$ бурового раствора. После разбуривания цементного моста в интервале 1130-1177 м скважину промыли и подняли инструмент.

После смены КНБК инструмент спустили на бурение. При бурении на глубине 1179 м пропала циркуляция бурового раствора, интервал 1179-1182 м, пробурен без выхода циркуляции, скважина поглотила $33 \mathrm{~m}^{3}$ бурового раствора. Подняли инструмент.

Спустили инструмент с открытым концом СБТ 127 для изоляционной заливки зоны поглощения. Закачку цемента производили на глубине 1115 м, в скважину было закачано 8,9 м

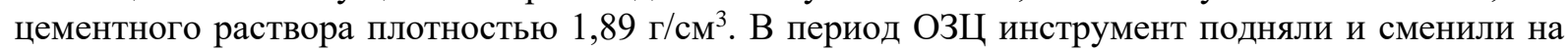
компоновку для бурения. При спуске произвели промежуточную промывку на глубине 853 м. При проработке ствола скважины в интервале 1166-1176 м возобновилось поглощение бурового раствора без выхода циркуляции. Подняли инструмент, заготовили буровой раствор, сменили КНБК и приступили к спуску. На глубине 888 м произвели промежуточную промывку, после закачки $10 \mathrm{~m}^{3}$ бурового раствора циркуляция восстановилась. На глубине $1176 \mathrm{~m}$ произвели следующую промывку, которая привела к возобновлению поглощения и потере циркуляции, скважина поглотила $18 \mathrm{~m}^{3}$ бурового раствора. Дальнейшая проработка в интервале 1176-1182 м и бурение в интервале 1182-1183 м велись без выхода циркуляции. С глубины 1183 м произвели подъем инструмента в башмак кондуктора. Заготовили 95,3 м³ бурового раствора, спустили инструмент на забой. Бурение в интервале 1183-1186 м велось без выхода циркуляции, расход раствора составил $60 \mathrm{~m}^{3}$. Инструмент подняли в башмак кондуктора, набрали воды в объеме $70 \mathrm{~m}^{3}$.

Бурение в интервале 1186,0-1214,3 м производили на воде без выхода циркуляции, при этом скважина поглотила $630 \mathrm{~m}^{3}$ технической воды. При забое 1214,3 м инструмент подняли и спустили в скважину открытый конец СБТ 127 на глубину 1187 м для изоляционной заливки установкой цементного моста. В скважину закачали $10 \mathrm{~m}^{3}$ цементного раствора плотностью 1,84 г/см³. После ОЗЦ спустили компоновку на бурение, промыли скважину на глубине 1169 м, циркуляция 100 \%. При разбуривание цементного моста в интервале 1169-1214 м наблюдалось частичное поглощение промывочной жидкости. При достижении глубины 1216 м произвели подъем инструмента и смену КНБК. 
При проработке скважины в интервале 1190-1204 м поглощение промывочной жидкости составило 7-8 м³/час. При бурении в интервале 1216-1247 м поглотило $60 \mathrm{~m}^{3}$ промывочной жидкости. При забое 1247 м произвели подъем КНБК, спустили открытый конец

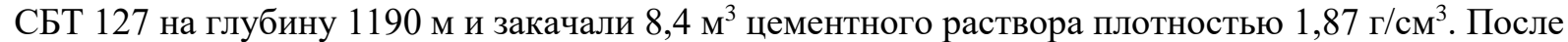
ОЗЦ спустили КНБК на бурение. Во время спуска и проработки скважина поглощала 7-8 м3/час промывочной жидкости. При разбуривании цементного моста в интервале 1130-1140 м поглощение составило $12 \mathrm{~m}^{3} /$ час. Подняли КНБК и передали скважину для проведения геофизических исследований.

При спуске прибор остановился на глубине 930 м. Произвели проработку ствола скважины в интервале 892-1140 м. После проработки приборы не проходили ниже глубины 920 м.

По окончанию геофизических работ в скважину спустили открытый конец СБТ 127 на глубину 966 м и произвели закачку $8,5 \mathrm{~m}^{3}$ цементного раствора плотностью $1,82 \mathrm{r} / \mathrm{cm}^{3}$. По истечению срока ОЗЦ в скважину спустили КНБК на бурение. При разбуривание цементного моста наблюдалось поглощение промывочной жидкости в интервале 1040-1044 м. С глубины 1044м произвели подъем и смену КНБК. Разбурили цементный мост в интервале 1044-1054 м и подняли инструмент.

В скважину спустили открытый конец СБТ 127, произвели замер кривизны инклинометром, после чего подняли инструмент и спустили КНБК на бурение. Продолжили разбуривание цементного моста в интервале 1030-1129 м. При бурении наблюдалось частичное поглощение промывочной жидкости 10-12 м³/час.

На глубине 1129 м произошел прихват бурового инструмента. Инструмент освободили в результате расхаживания. Произвели подъем и смену КНБК. В интервале 1136-1140 м произошло поглощение промывочной жидкости в объеме $17 \mathrm{~m}^{3}$. На глубине 1140 м произвели закачку $10 \mathrm{~m}^{3}$ высоковязкого бурового раствора. Закачка второй пачки высоковязкого бурового раствора, с наполнителем в объеме $10 \mathrm{~m}^{3}$, при закрытом превенторе, привела к восстановлению циркуляции. На восстановление циркуляции израсходовано $6 \mathrm{~m}^{3}$ бурового раствора. После двухчасовой технической стоянки на восстановлении циркуляции израсходовано $2,6 \mathrm{~m}^{3}$ бурового раствора. Инструмент спустили на забой - поглощение отсутствовало. При разбуривание цемента в интервале 1140-1162 м появилось частичное поглощение бурового раствора. При достижении глубины 1173 м в скважину закачали $10 \mathrm{~m}^{3}$ вязкой упругой смеси. Произвели подъем инструмента.

Во время спуска инструмента наблюдалось частичное поглощение бурового раствора. При достижении глубины 1170 м в скважину закачали $15 \mathrm{~m}^{3}$ бурового раствора высокой вязкости. При забое 1189 м закачали $10 \mathrm{~m}^{3}$ высоковязкого бурового раствора. На глубине 1207 м закачали 15 м $^{3}$ высоковязкого бурового раствора. Бурение продолжили и при забое 1226 м закачали еще $10 \mathrm{~m}^{3}$ высоковязкого бурового раствора. Поглощение в объеме 4-5 $\mathrm{m}^{3} /$ час возобновилось при забое 1232 м, по достижению забоя 1254 м в скважину закачали $15 \mathrm{~m}^{3}$ высоковязкого бурового раствора. При бурении интервала 1254-1264 м поглощение составляло $6 \mathrm{~m}^{3} /$ час. При забое 1264 м закачали $12 \mathrm{~m}^{3}$ высоковязкого бурового раствора, после чего скважину перевели на глинистый раствор в объеме $60 \mathrm{~m}^{3}$. Циркуляция восстановилась после закачки $5 \mathrm{~m}^{3}$ раствора. В раствор ввели $4 \mathrm{~m}^{3}$ наполнителя в виде опилок. Во время проработки интервала 1120-1264 м поглощение составляло1 м³/час.

Бурение в интервале 1264- 1487 м велось с незначительными потерями бурового раствора, поглощение составляло приблизительно $0,8 \mathrm{~m}^{3} /$ час.

При забое 1487 м произошел слом инструмента. «Голова» сломанного инструмента находилась на глубине 926,7 м. Во время спуска в скважину ловильного инструмента на восстановление циркуляции задействовано 14,5 м³ бурового раствора. Аварийно-ловильные работы на глубине 926 м проводились 6 дней, положительного результата не достигли. Приняли решение перебурить аварийный интервал вторым стволом.

Скважину перевели на техническую воду. Во время установки ликвидационного цементного моста в скважину закачано $10 \mathrm{~m}^{3}$ цементного раствора плотностью 1.82 г/ $\mathrm{cm}^{3}$. «Голова» ликвидационного цементного моста определена нащупыванием инструментом на глубине 905,74 м, цементный мост разбурили в интервале 905,74-911,0 м. При установке второго цементного моста в скважину закачали 4,7 $\mathrm{m}^{3}$ цементного раствора плотностью 
1,82 г см $^{3}$. «Голова» цементного моста определена на глубине 870 м, мост разбурили в интервале 870-896 м.

Забуривание второго ствола скважины произвели в интервале 896 - 899,9 м, шлам был представлен цементом $45 \%$ и известняком 55\%, в интервале 899,9-902,5 м шлам представлен цементом 20\%, известняком 80\%. При бурении второго ствола в интервале 908-919 м шлам представлен известняком $100 \%$. При забое второго ствола на глубине 931 м скважина была переведена на глинистый раствор. Во время СПО с проработкой скважины КЛС «садится»на глубине 931,11 м. Интервал 931-937 м неоднократно прорабатывали и шаблонировали райбером без вращения КЛС, после чего бурение продолжили. Провели замер кривизны инклинометром. Проработали скважину, во время проработки скважины КЛС «садится» на глубине 949 м. Путем расхаживания инструмента на 20 тн сверх собственного веса (собственный вес 41тн) и с проворотом ротором инструмент был освобожден.

Продолжили бурение в интервале 1132-1171 м, скважина поглотила буровой раствор в объеме 45,3 $\mathrm{m}^{3}$, затем закачано $30 \mathrm{~m}^{3}$ тампона и еще $60 \mathrm{~m}^{3}$ тампона (содержание тампона опилки $1 \mathrm{~m}^{3}$ и резиновая крошка 2,6 т).

При бурении в интервале 1171-1178 м скважина поглотила 3 м интервале 1178-1181 м скважина поглотила $40 \mathrm{~m}^{3}$ бурового раствора без выхода циркуляции. Произвели подъем инструмента в интервале 1181-844 м и закачали раствор с тампоном в объеме $10 \mathrm{~m}^{3}$, с глубины 844 м подняли инструмент до устья с разборкой КНБК.

После заготовки глинистого раствора в объеме $32 \mathrm{~m}^{3}$, был определен статический уровень на глубине 111 м от устья скважины. Спустили инструмент СБТ 127 с открытым концом на глубину 1124 м. Произвели закачку тампона в объеме 12,6 м ${ }^{3}$ - возобновление циркуляции произошло после закачки $6 \mathrm{~m}^{3}$, на глубине 1178 м произвели повторную закачку тампона в объеме $12,3 \mathrm{~m}^{3}$ - возобновление циркуляции произошло после закачки 7,7 $\mathrm{m}^{3}$ тампона.

Для ликвидации зоны поглощения произвели установку цементного моста, открытый

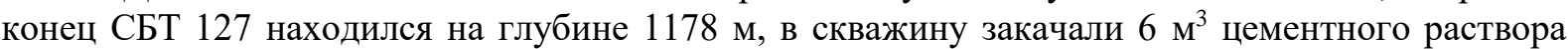
плотностью 1,84 г/ $\mathrm{cm}^{3}$.

После ОЗЦ в скважину спустили новую компоновку (долото 295,3СЗГАУ). В качестве промывочной жидкости применили полимерглинистый раствор с параметрами: плотность 1,04-

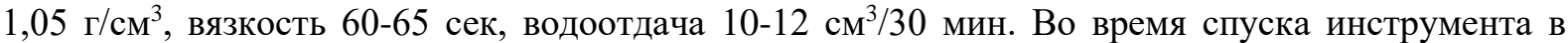
интервал 489-1026 м произошла посадка инструмента, циркуляция восстановилась после закачки $12 \mathrm{~m}^{3}$ бурового раствора. Проработали интервал 1026-1181 м - поглощение составило $3 \mathrm{~m}^{3}$, при бурении в интервале 1181-1187 м - поглощение составило 9 м $^{3}$. Промыли скважину перед подъемом инструмента на глубине 1187 м, циркуляция $100 \%$, статический уровень отбит на глубине 30 м от устья. Заготовили буровой раствор в объеме $55 \mathrm{~m}^{3}$ и продолжили проработку в интервале 1026-1060 м, поглощение составило $4 \mathrm{~m}^{3}$. Углубление скважины продолжилось с глубины 1187 м. При бурении интервала 1197-1199 м поглощение составляло 2,3 м³/час.

При достижении глубины 1217 м провели шаблонирование скважины, в интервале 1217-1163 м, происходили затяжки до 5 тн сверх собственного веса (собственный вес 56 тн). При подъеме инструмента в интервал 1217-881 м, возникали затяжки до 5 тн сверх собственного веса в интервале 1200-1015 м. После ремонта АКБ и цепи быстрого хода, была проведена проработка интервала 1002-1217 м. Продолжили бурение в интервале 1217-1220 м. Пробурили интервал 1220-1255 м, в интервале 1220-1244 м поглощение составило 5 м $^{3}$. Произвели подъем и смену компоновки. При спуске КНБК произвели проработку интервала 1205-1215 м и продолжили бурение в интервале 1255-1286 м. При забое 1286 м произвели промывку скважины с последующим подъемом инструмента в интервал 1286-890 м. Промыли скважину на глубине 890 м и спустили на забой. Пробурили в интервале 1286-1449 м, в интервале 1388-964 м прошаблонировали скважину.

Подготовили скважину к геофизическим исследования. Провели замер кривизны инклинометром. Скважина заполнена полимерглинистым буровым раствором с параметрами:

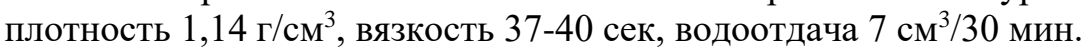

Пробурили интервал 1449-1475 м, подняли инструмент с контролем дефектоскопией, отбраковано СБТ 127 «L» 41 труба, СБТ 127 «G» 3 трубы. Сменили компоновку, проработали 
интервал 1462-1475 м и промыли скважину, произвели подъем инструмента и смену компоновки.

Спустили инструмент и пробурили с глубины 1475 м до 1537 м, произвели подъем инструмента в интервал 1537-880 м, при подъеме возникали небольшие затяжки до 5 тн сверх собственного веса (собственный вес 69 тн) в интервале 1480-1430 м. Заготовили буровой раствор в объеме $30 \mathrm{~m}^{3}$.

При спуске инструмента в интервал 880-1440 м произошла посадка инструмента, произвели разгрузку на 2 тн и проработку в интервале 1140-1537 м. Бурение велось в интервале 1537-1544 м. При спуске инструмента в интервал 880-1530 м вновь произошла посадка инструмента, проработали интервал 1530-1544м. Продолжили бурение в интервале 15441667 м. Произвели подъем инструмента с глубины 1667 м до устья, при подъеме возникали затяжки до 7 тн сверх собственного веса.

Проработали ствол скважины в интервале 1511-1667 м, продолжили бурение в интервале 1667-1676 м. Подняли инструмент со сменой компоновки. Произвели чистку емкостей и желобов от шлама. Перевели скважину на хлор-калиевый буровой раствор (в объеме $60 \mathrm{~m}^{3}$ ) с параметрами: плотность 1,15 г/ $\mathrm{cm}^{3}$, вязкость $51-55$ сек, водоотдача $8 \mathrm{~cm}^{3} / 30$ мин. Бурение велось в интервале 1676-1953 м, перед каждым наращиванием производилась промывка скважины 15-30 мин.

При забое 1953м произвели подъем инструмента под каротаж. Комплекс ГИС включал: стандартный каротаж, БК, РК, АК, инклинометрию.

Произвели смену компоновки и продолжили бурение в интервале 1953-2122 м. Произвели замер параметров траектории ствола инклинометром. С глубины 2118 м зенитный угол составляет 4,8 . После ГИС бурение продолжили, прошли интервал 2122-2202 м. Произвели подъем инструмента для смены долота. При подъеме происходили небольшие затяжки до 6-8 тн сверх веса инструмента в интервале 2060-2020 м. При отвороте долота обнаружены следы работы по металлу, особенно большая выработка в верхней части лап долота.

Спустили магнитный фрезер для очистки забоя скважины от металла. После очистки забоя магнитным фрезером пробурили интервал 2202-2327,6 м и произвели подъем инструмента.

Выявлен слом инструмента, в скважине осталось 48,5 м инструмента, «голова» оставленного инструмента находится на глубине 2327,6 м. Приступили к аварийно-ловильным работам. Спустили метчик МБУ74, навернулись в «голове» и подняли из скважины остаток инструмента.

Продолжили бурение в интервале 2327,6-2400 м.

При забое 2400 м выполнили комплекс ГИС под промежуточную колонну, включающий: стандартный каротаж, резистивиметрия, ПС, кавернометрия, БК, АК, РК, инклинометрия, термометрия.

После проведения ГИС произвели проработку скважины перед спуском промежуточной колонны. Во время проработки в интервале 1078-1105 м произошло поглощение в объеме 16 м $^{3}$ за 8 часов, в интервале $1105-1120$ м поглощение составило $5 \mathrm{~m}^{3}$, в раствор ввели $3 \mathrm{~m}^{3}$ опилок. После проработки при подъеме инструмента в интервале 2400-2340 м возникли затяжки до 7 тн сверх собственного веса, в интервале 2376-2400 м провели повторную проработку скважины.

Спустили обсадную колонну на глубину 2400 м и зацементировали до устья. После ОЗЦ разбурили цементный стакан в интервале 2375-2402 м, закачали 1 м $^{3}$ воды, опрессовали цементное кольцо давлением 168 атм, герметично. Пробурили интервал 2402,0-2405,5, подняли инструмент.

Провели ГИС (цементометрия, АКЦ).

Спустили инструмент на бурение (долото 215,9 мм), для промывки использован

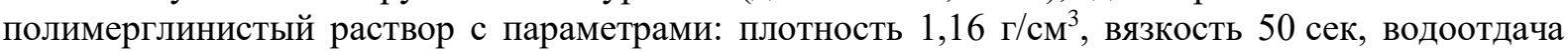
$7,2 \mathrm{~cm}^{3} / 30$ мин, СНС 4/30. Прошли интервал 2405,5-2615 м. При бурении в интервале 25062527 м наблюдались затяжки до 5 тн сверх собственного веса, провели технологический подъем до глубины 2396 м и спуск с проработкой в местах посадки. Подъем инструмента с затяжками до 8 тн в интервалах 2585-2580 м, 2464-2457 м, 2420-2413 м.

При забое 2615 м проведен полный комплекс промыслово-геофизических исследований. 
Спустили инструмент и бурили в интервале 2615-2645 м.

Подняли инструмент, собрали керноотборный снаряд «Кембрий» (бурильная головка $\mathrm{ST}_{212,7 / 100}$ ), бурение с отбором керна в интервале 2645-2656 м, проходка с отбором керна $11 \mathrm{м}$, вынос керна 11 м - 100\%, керн представлен известняками и доломитами без признаков углеводородов.

Спустили инструмент с промывкой и проработкой в интервале 2579-2595 м, бурение в интервале 2656-2666 м. Подняли инструмент, подготовили скважину к геофизическим исследованиям.

Выполнили комплекс промыслово-геофизических исследований.

Спустили КНБК с промывкой на глубине 2260 м и проработкой в интервале 26662689 м, бурение в интервале 2689-2723 м.

При подъеме инструмента в интервале 2723-2584 м произошел прихват. Ликвидацию аварии проводили расхаживанием инструмента, установкой двух нефтяных ванн и сбиванием инструмента вниз. Подъем инструмента осуществляли с проворотом ротором в интервале 2598 2604, дальше инструмент пошел свободно. Разобрали и собрали КНБК.

Спустили инструмент с промывкой и проработкой в интервале 2710-2723 м, буровой раствор полимер-ингибированный с параметрами: плотность $1,16 \mathrm{r} / \mathrm{cm}^{3}$, вязкость 65 сек, водоотдача $5 \mathrm{~cm}^{3} / 30$ мин.

Бурение в интервале 2723-2801 м. Подняли инструмент, сменили компоновку, спустили, промыли на забое. Бурение в интервале 2801-2879 м. Подъем инструмента в интервале 28702570 м с промывкой и проработкой (затяжки до 6-8 тн). Спустили инструмента без посадок до забоя. Бурение в интервале 2879-3018 м, промыли скважину и подготовили к проведению геофизических исследований.

Выполнили комплекс промыслово-геофизических исследований.

Сменили компоновку и спустили инструмент на бурение. Пробурили интервал 30193088 м. Подняли инструмент с проведением дефектоскопии, отбраковано 44 трубы. Инструмент спустили до забоя, промыли скважину и пробурили в интервале 3088,0-3104,4 м, произвели технологическую промывку, подняли инструмент. Подготовили скважину и инструмент для бурения с отбором керна.

Спустили КНБК с керноотборным снарядом «Кембрий» и пробурили с отбором керна интервал 3104,4-3110 м, проходка с отбором керна - 5,6 м, вынос керна - 5,6 м или 100\%, керн представлен известняком с выпотами нефти и слабым запахом углеводородов.

Собрали компоновку и спустили на бурение, пробурили в интервале 3110-3153 м, промыли скважину перед подъемом, подняли инструмент.

Спустили КНБК с керноотборным снарядом «Кембрий» и пробурили с отбором керна интервал 3153-3158 м, проходка с отбором керна - 5 м, вынос керна - 3 м или 60\%, керн представлен известняком без признаков углеводородов.

Собрали КНБК, спустили и произвели расширку ствола скважины в интервале 31533158 м, бурение продолжили в интервале 3158-3281 м, произвели технологическую промывку и подняли инструмент.

Скважину подготовили к выполнению комплекса ГИС. При спуске зонд стандартного каротажа встал на глубине 2462 м. Неоднократные попытки продвинуть зонд глубже результата не дали. Спустили инструмент с промывкой и проработкой в интервалах посадки: 2364-2495 м, 2495-2510 м, 2510-2520 м, 2520-2529 м, 2529-2537 м, 2537-2544 м. Подъем осуществляли с проворотом и расхаживанием в интервале 2419-2398 м.

Сменили долото и спустили инструмент до глубины 2475 м, далее спуск после каждого наращивания с проработкой и промывкой до забоя, бурение в интервале 3281-3282 м.

Подняли инструмент и подготовили скважину к проведению ГИС. Первым спустили в скважину каверномер, который встал на глубине 2467 м, термометр встал так же на глубине 2467 м. Провели запись стандартного, бокового, индукционного акустического каротажей. Собрали КНБК, провели шаблонирование скважины до забоя и подняли инструмент. Произвели запись РК, ГГК-П, микрозондов. Прибор импульсного каротажа встал на глубине 2467 м. Нижний открытый конец инструмента оборудовали воронкой и спустили на глубину 2505 м. Произвели запись приборами ИННК и скважинный термометр до забоя скважины. 
Собрали КНБК, спустили до забоя и пробурили в интервале 3282-3310 м. Подняли инструмент до глубины 2360 м и визуально установили промыв одной трубы по телу. Спустили инструмент до забоя и пробурили в интервале 3310-3400 м, произвели технологическую промывку скважины и технологический подъем до глубины 1468 м. Собрали СБТ 114 Л 15 штук с мостков, спустили инструмент и продолжили бурение в интервале 3468-3497 м.

Подняли инструмент, сменили компоновку и спустили на бурение в интервале 34973621 м, промыли скважину, подняли инструмент, сменили компоновку.

Спустили инструмент на бурение в интервале 3621-3779 м. Технологическая промывка и технологический подъем в интервале 3779-2630 м, затяжки до 4 тн на глубинах: 3601 м, 3368 м, 3292 м, 3827 м подняли инструмент до глубины 2392 м. Спустили инструмент в интервале 2392-3779 м. Бурение в интервале 3779-3845,8 м, подняли инструмент.

Собрали и включили в компоновку керноотборный снаряд «Кембрий», спустили инструмент с промежуточными промывками на глубинах: 2394 м, 2700 м, 2986 м, 3400 м, 3827 м, бурение с отбором керна в интервале $3845,8-3851,4$ м. Подняли инструмент, разобрали керноотборный снаряд, извлекли керн. Проходка с отбором керна составила - 5,6 м, вынос керна - 5,6 м или $100 \%$, керн представлен алевритистым аргиллитом и песчаником без признаков углеводородов.

Спустили КНБК на глубину 3845 м, произвели расширку в интервале 3845-3851,4 м, бурение в интервале 3851,4-3880 м. Промыли скважину, подняли инструмент для проведения геофизических исследований.

Промыслово-геофизические исследования: прибор стандартного каротажа при спуске встал на глубине 2465 м, неоднократные попытки протолкнуть прибор результатов не дали, каверномер с удлинителем встал на глубине 2465 м.

Спустили инструмент с воронкой на открытом конце СБТ 127 на глубину 2470 м с перекрытием места непрохождения приборов. Выполнили термометрию, кавернометрию, индукционный каротаж, РК, инклинометрию до глубины 3880 м. Подняли инструмент с воронкой, повторили попытку спуска стандартного каротажа, прибор встал на глубине 2465 м.

Спустили компоновку для шаблонирования в интервалах 2429-2467 м, 2467-2495 м и проработки интервалов 3860-3876 м, 3876-3880 м с промывкой на забое в течение двух часов.

Возобновили проведение промыслово-геофизических исследований: записали кавернометрию в интервале 2560-2360 м, акустический каротаж в интервале 3880-3200 м, микрозонд не прошел.

Спустили СБТ с воронкой на глубину 2470 м. ГИС через инструмент: выполнили стандартный каротаж и резистивиметрию в интервале 3880-3200 м. Подняли воронку, попытка записи микрозонда не удалась. Прибор встал на глубине 2465 м.

Спустили воронку для проведения ВСП, во время записи ВСП произошел обрыв кабеля. В скважине остались три зонда ВСП с кабелем. Выполнили аварийные работы по извлечению оборванных зондов спуском ловителей и торцевого фреза. Извлечь зонды с кабелем не удалось, они были сбиты на забой скважины.

В связи с отсутствием признаков нефтенасыщения в интервале 3220-3880 м нижняя часть ствола скважины ликвидируется установкой цементных изолирующих мостов.

Один цементный мост установили в интервале 3790-3880 м, закачано 5,5 м раствора плотностью 1,82 г/ $\mathrm{cm}^{3}$, израсходовано 7,0 т сухого цемента. После ОЗЦ голова цементного моста определена на глубине 3700 м и испытана разгрузкой на 5 т.

Второй цементный мост установили в интервале $3210-3285$ м, закачано $3,1 \mathrm{~m}^{3}$

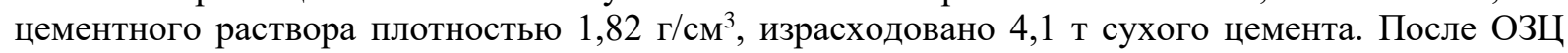
цементный мост не обнаружен.

Повторили установку цементного моста в интервале 3210-3300 м, закачано 6 м $^{3}$ тампона с добавлением опилок, продавлено буровым раствором в объеме $27 \mathrm{~m}^{3}$, затем закачано 5,5 $\mathrm{m}^{3}$ цементного раствора плотностью 1,82 г $/ \mathrm{cm}^{3}$, израсходовано 5,0 т сухого цемента. После ОЗЦ «голова» цементного моста определена на глубине 3237,1 м и испытана разгрузкой на 5 т.

После промывки скважины и выброса инструмента на мостки начали спуск эксплуатационной колонны диаметром 146 мм. Спущено 283 трубы общей длиной 3226,38 м. 
Проведено цементирование эксплуатационной колонны, закачано $45,8 \mathrm{~m}^{3}$ цементного раствора плотностью $1.89 \mathrm{r} / \mathrm{cm}^{3}$, продавлено глинистым раствором плотностью 1,16 г/ $\mathrm{cm}^{3}$ в объеме $43,25 \mathrm{~m}^{3}$ раствора.

Провели термометрию скважины для контроля высоты подъема цемента. Уровень цемента за колонной отбивается на глубине 1580 м.

В скважину спустили «перо» + НКТ 73 мм в количестве 334 труб, на глубину 3194 м. Буровой раствор заменен на техническую воду.

Опрессовали межколонное пространство избыточным давлением 81 атм, герметично.

Опрессовали колонну 146 мм избыточным давлением 125 атм, герметично.

Провели контроль герметичности эксплуатационной колонны диаметром 146 мм снижением уровня свабом до глубины 1100 м, колонна признана герметичной.

Скважину перевели на буровой раствор плотностью 1,17 г/см³ для проведения ВСП.

Провели ГИС: АКЦ, ГК, ЛМ, ВСП.

В скважину спустили НКТ 73 мм с воронкой на глубину 3083,94 м, всего 320 труб.

Буровой раствор в скважине заменили на воду плотностью 1,0 г $/ \mathrm{cm}^{3}$.

На устье скважины смонтировали фонтанную арматуру АФК-65×35ХЛ № 13 [2, 3, 4].

Строительство скважины завершено. При этом только на борьбу с осложнением, представленным поглощением бурового раствора израсходовано более $800 \mathrm{~m}^{3}$ бурового раствора и порядка 70 т сухого тампонажного цемента, не считая затрат времени. Произошло 8 аварий, в том числе 5 прихватов, 2 слома инструмента и один обрыв кабеля с геофизическим прибором при соответствующих затратах времени на их ликвидацию.

Скважина 4024 ЧРП, при бурении «кармана» под спуск компоновки на бурение бокового ствола, режим бурения: нагрузка 14-16 тн, давление 36-38 атм, обороты ротора 2630 об/мин производительность насосов 25 л/с, при отрыве от забоя на глубине 1146,2 м произошла затяжка инструмента сверх собственного веса на 25 тн, с резким падением веса до собственного 32 тн. Инструмент расходили от забоя до «окна» 1138 м три раза при этом были затяжки инструмента до 6 тн. При очередном подъеме инструмента произошло резкое падение давления с 36 до 25 атм и недохождение инструмента 3 м до забоя. После подъема установлено, что произошел слом фрезера по муфте ФР2-220. В скважине осталось: ФО2-200 + ФР2-220. «Голова» аварийного слома на глубине 1143,2 м. При осмотре слома визуально установлена неоднородность структуры металла, скрытые микротрещины по сечению слома ФО2-220 [2, 3]. На ликвидацию аварии затрачено 33 часа 42 минуты.

Скважина № 4004 ЧРП бурилась с промывкой полимерным хлоркалиевым буровым раствором с параметрами: плотность 1,10 г/ $\mathrm{cm}^{3}$, условная вязкость $45 \mathrm{c}$, фильтрация $5,7 \mathrm{~cm}^{3} / 3 \mathrm{a}$ 30 мин, смазка 8 \%. При достижении забоя 2384,4 м было принято решение произвести подъем инструмента для смены долота SL62AKPR диаметром 142,9 мм. Наработка на долото составляла 28 часов 46 минут. Во время промывки перед подъемом производили расхаживание бурового инструмента на величину не более 5 метров без вращения ротором. Время промывки составило 40 минут. Расчетное время одного цикла промывки составляет 52 минуты. Отключив буровые насосы отвернули ведущую бурильную трубу и приступили к подъему инструмента. Собственный вес бурильного инструмента при движении вверх составил 38 тн. При подъеме первой свечи на первой трубе допустили затяжку до 60 тн (22 тн сверх собственного веса). Дальнейшие действия предполагали наворот ведущей трубы и проведение работ с обязательной циркуляцией раствора. Однако навернуть ведущую бурильную трубу не представлялось возможным из-за того, что муфта трубы для наворота согнута, решили поднять инструмент, чтобы отвернуть трубу с согнутой муфтой. В момент нахождения резьбового соединения труб первой свечи на роторной площадке затяжка составляла 22 тн сверх собственного веса. Посадив инструмент в клинья, под натяжкой произвели отворот первой трубы. Навернули ведущую бурильную трубу, включили насос с минимальной производительностью. По показаниям манометра наблюдался рост давления до 170 атмосфер, а выход бурового раствора отсутствовал. Незамедлительно приступили к расхаживанию бурильного инструмента. Попытки восстановить циркуляцию с помощью насоса агрегата ЦА-320 результата не дали. С целью ликвидации аварии произвели натяжку бурильного инструмента на 54 тн сверх собственного веса, вследствие чего 
произошел обрыв бурильного инструмента СБТ-73 $\times 9,19$. Из скважины было поднято 20 труб и 5 метров оборванной трубы, что в сумме составило 195 метров.

Произвели спуск и наворот «колокола» К 95-60, отвернули и подняли бурильный инструмент. Поднято дополнительно 223 м бурильного инструмента. Аварийная «голова», представленная муфтой бурильного инструмента, находится на глубине 418 м.

Произвели спуск и наворот СБТ-73 на аварийную «голову» с восстановлением целостности бурильного инструмента. В процессе докрепления замковых соединений бурильного инструмента при натяжении 26 тн и 29 тн вращение отсутствовало. Произвели расхаживание бурильного инструмента до $45 \mathrm{TH}$ - результат отрицательный. Произвели две попытки отворота бурильного инструмента на глубине 1800 м - результат отрицательный. После второй неудачной попытки отворота, при исходном весе 7,5 тн, произвели подъем 399 м с целью ревизии бурильного инструмента с последующим спуском и докреплением замковых соединений машинными ключами.

Произвели наворот бурильного инструмента с последующей записью ГИС (ГК, ЛМ, прихватоопределитель) в СБТ-73. Приборы ниже глубины 2260 м не проходили. С целью минимизации изгибов бурильного инструмента при записи ГИС, произвели натяжку до 45 тн, после чего появилось движение бурильного инструмента вверх. Авария ликвидирована подъемом аварийной КНБК. Время на ликвидацию аварии составило 126 часов 30 минут [3, 4].

На примере трех скважин, пробуренных до проектной глубины, рассмотрены сложные случаи борьбы с поглощением бурового раствора и ликвидации аварий при бурении скважин и боковых стволов. На материалах пробуренных скважинах показаны не только сами осложнения и аварии, но и предшествующий им процесс бурения и последующая ликвидация практически во всех деталях. Идея работы заключена в том, чтобы показать, что, не смотря на казалось бы хорошо изученные процессы осложнений и аварийных ситуаций и наработанный опыт их ликвидации при бурении скважин, каждая отдельная скважина индивидуальна и рассматриваемые протекающие при ее бурении процессы имеют определенные отличительные особенности, которые и необходимо учитывать при ликвидации каждого отдельного осложнения и аварии.

\section{ЛИТЕРАТУРА}

1. Антонов К.В. Бурение скважин учебное пособие/ сост. К.В. Антонов, Р.А. Валиуллин, И.Г. Низаева / Под редакцией канд. техн. наук, доцента К.В. Антонова. - Уфа: РИЦ БашГУ, 2018. - 344 с.

2. Винниченко В. М. Предупреждение и ликвидация осложнений и аварий при бурении разведочных скважин. / В. М. Винниченко, А. Е. Гончаров, Н. Н. Максименко - М.: Недра, 1991. - 170 с.

3. Правила безопасности в нефтяной и газовой промышленности. - ПБ 08-624-03. - СПб.: Издательство ДЕАН, 2005. $-305 \mathrm{c}$.

4. Пустовойтенко И. П. Предупреждение и ликвидация аварий в бурении. / И.П. Пустовойтенко - М.: Недра, 1988. - 279 c. 